Милица М. Савић

Филозофски факултет Универзитета у Новом Саду

Докторанд на Методици наставе

millysavic@yahoo.com

\title{
МОДЕЛИ ПРОСТЕ РЕЧЕНИЦЕ С ОБЗИРОМ НА ТИПОВЕ СУБЈЕКТА У НАСТАВИ СРПСКОГ ЈЕЗИКА ${ }^{1}$
}

\section{Сажетак}

\begin{abstract}
У раду се, на основу релевантне лингвистичке и методичке литературе, сагледавају могућности за припремање наставне јединице из српског језика о субјекту као једном од основних реченичних конституената и његовој типологији. Описује се методички модел заснован на савременим методичким системима и пружају смернице за ефикасно изучавање сложене грађе о моделима просте реченице са граматичким и семантичким (логичким) субјектом у средњој школи уз помоћ уџбеника и полупрограмираног материјала.
\end{abstract}

Кључне речи: методика наставе српског језика, синтакса, проста реченица, логички субјекат, полупрограмирани материјал

\section{1. УВОД}

Бројни лингвисти и методичари већ дуго упозоравају на чињеницу да је настава језика у средњој школи углавном запостављена, при чему је обрада грађе из граматике у подређеном положају у односу на садржаје из књижевности. Премда су у актуелним наставним плановима и програмима за средње стручне школе и гимназије истакнути садржаји из језика које треба обрадити, често није прецизирано у ком обиму се неко градиво изучава. Како би се подстакло учење језика у школама, неопходно је уз програме јасно одредити наставна средства потребна за њихову реализацију, затим пружити упутства наставницима о методама за презентовање садржаја из граматике,

1 Овај рад је резултат испитивања које је ауторка, стипендиста Министарства просвете, науке и технолошког развоја, спровела у оквиру докторских студија Методике наставе под менторством проф. др Љиљане Петровачки. 
те посебну пажњу усмерити на примену стечених знања у складу са потребама одређеног образовног профила.

У филолошким гимназијама комплексно градиво о моделима просте реченице детаљно се обрађује, али су тако корисна упутства ипак изостала. Наставним планом и програмом у трећем разреду средње школе предвиђено је обнављање знања о субјекатско-предикатској реченици као основном моделу просте предикатске реченице, затим проширивање знања о субјекту, као и детаљније упознавање с реченицама са логичким субјектом, али и неким новим типовима просте реченице - егзистенцијалним, обезличеним и безличним реченицама, као и пасивним конструкцијама. Нарочито је битно да приликом обраде тако сложене грађе буду примењени методички приступи који ће оспособити ученика за самостално акционо истраживање, односно тумачење и усвајање појмова из синтаксе просте реченице, и обезбедити трајност и примењивост стечених знања, као и постизање индивидуализације и диференцијације на часовима српског језика.

Представљањем иновација у области методике наставе српског језика, али и непосредно, кроз припрему и презентовање наставних јединица намењених за обраду поменуте грађе које би послужиле као модел, може се подстаћи остварење активне и креативне улоге наставника, као и примена савремених методичких система погодних за језичку наставу. Сматрамо да се ученици на тај начин могу ваљано мотивисати за изучавање градива из граматике, што је и основни предуслов успешног и ефикасног учења на часовима српског језика. Потребно је, дакле, пружити наставницима конкретне смернице, са детаљним упутствима за рад, што ће несумњиво допринети побољшању и унапређењу наставне праксе и њеном усклађивању са савременим токовима у методичкој науци.

Размотрили смо зато могућности примене иновативних методичких приступа при обради грађе о моделима просте реченице са различитим типовима субјекта у трећем разреду средње школе и осмислили дидактичко-методички модел наставне јединице у којем се такве реченичне структуре откривају и анализирају уз помоћ уџбеника и полупрограмираног материјала, за који сматрамо да је примерен обради овако комплексног градива из граматике српског језика.

\section{2. МЕТОДИЧКА РАЗРАДА}

У Граматици српског језика, аутора Љубомира Поповића и Живојина Станојчића, која се углавном користи у средњим стручним школама и гимна- 
зијама, презентована су теоријска одређења граматичког и логичког (семантичког) субјекта и укратко представљене њихове формалне карактеристике. Сматрамо да су лекције из уџбеника веома корисне као добар полазни текст у откривању нових модела просте реченице, али је неопходно, са друге стране, да се ученици активно укључе у анализу тих реченичних конструкција, што се може постићи употребом пажљиво осмишљеног предлошка, односно полупрограмираног материјала. Наставник ће се тако определити за методички приступ који осигурава активно изучавање грађе о новим типовима просте реченице.

У таквом методичком приступу кроз разноврсне задатке и теоријска питања ученици треба да увиде како се субјекту, заправо, приписује садржина глагола у предикату, те да таква двострана синтаксичка веза може бити обележена њиховим слагањем (конгруенцијом) у лицу, броју и роду, и тада проста реченица садржи тзв. граматички субјекат. Тај типичан облик српске предикатске реченице подразумева да је сваки од поменутих реченичних чланова независан, слободан. Субјекат при том може бити исказан употребом различитих синтаксичких јединица, односно речју, синтагмом и реченицом и може заузимати различите позиције у реченици, у зависности од реченичне перспективе и комуникативних потреба говорника (Поповић, Станојчић 1999: 221). Битно је, такође, да открију како је у простој реченици могуће изоставити субјекатски аргумент, који се онда реконструише на основу морфолошких аспеката глагола или именске речи у служби предиката.

С обзиром на то да конгруенција између субјекта и предиката у простој реченици неретко изостаје, треба их поступно упознати и са комплекснијим реченичним моделима, где се именска реч налази у зависном падежу и везује за неконгруентни, обично имперсонални предикат, као обавезни, неиспустиви реченични елемент. Лингвисти истичу да је у њима позиција субјекта условљена структурним ликом предиката, као у примерима: Cnaвa му се. Плаче јој се. Зева ми се. Да ми је знати! у којима је репрезентован тзв. логички или семантички субјекат, односно носилац психо-физиолошког стања или какве потребе приписане предикатом (Пипер и др. 2005: 480).

Да би ученици савладали градиво о моделима реченица са граматичким и логичким субјектом, неопходна је корелација и повезивање различитих знања из области морфологије, синтаксе и семантике, односно познавање свих елемената просте реченице, али и њихове типологије, односно одлика личних (персоналних) реченица, безличних и обезличених реченица и пасивних конструкција с обзиром на то да се оне често формирају са логичким субјектом. Циљ наставе је при том обнављање и утврђивање знања о простој реченици и њеним конституентима, а потом и асимилација новог предметног садржаја, 
односно интегрисање информација о новим моделима реченица и типовима субјекта у већ постојећу структуру знања. Овакав приступ подразумева, дакле, смислено изучавање градива коме је тежиште на укључивању нових информација у већ постојеће когнитивне структуре, при чему знања и појмови који се усвајају имају карактеристике целовитог система знања.

Стога смо креирали полупрограмирани материјал у коме је градиво разбијено на мање целине, па ученик прво обнавља знање о структурирању типичне субјекатско-предикатске реченице и граматичком субјекту, а потом уочава комплексније реченичне моделе са семантичким субјектом у дативу, акузативу и генитиву. ${ }^{2}$ Посебно се водило рачуна о његовом сегментирању и логичком рашчлањивању, како би се при обради грађе кретали „корак по корак” и стицали честицу по честицу знања (Петровачки 2010: 121; Илић 2003: 514), односно од појединачних примера ка апстрактнијим закључцима и описима, чиме се подстичу на концентрацију и максимално ангажовање, те се код њих развија способност индуктивно-дедуктивног закључивања, што је основа за учење путем откривања.

Пажљивим конструисањем задатака ваља, дакле, обезбедити учениково самостално откривање и анализирање формалних, односно морфосинтаксичких одлика логичког субјекта у реченицама, али и његових семантичких аспеката, који у уџбенику нису посебно истакнути. Представили смо зато функционални методички модел у коме је поменута програмска тема структурирана на нов начин, за активну наставу синтаксе. Тако ће ученици увидети да се у функцији логичког субјекта у простој реченици може користити именичка реч у дативу, затим да је у многим реченицама учестала употреба датива личне заменице, најчешће у енклитичком облику, али ће поред анализе граматичких средстава, кроз решавање проблема, посматрати и како је садржај обликован лексички и стилистички, те уочити да је поменутим семантичким субјектом у простој реченици означен носилац разноврсних ситуација, нпр: физиолошке потребе, физиолошког стања или процеса, осећања, расположења, нужде, могућности, умећа, сазнања воље, жеље и сл. На тај начин биће афирмисан тзв. унутрашњи принцип реченице, а примери реченичних конструкција сагледани као јединство садржаја и форме.

2 У раду ученика са материјалом мора бити обезбеђена поступност, што подразумева сазнајни пут који води од познатог ка мање познатом или непознатом, тежем и сложенијем. Методичари истичу да такав сазнајни смер одговара психологији учења и природном порасту знања. При томе је битна и оперативна мисао која усмерава и повећава домете поступности - систематичност, јер се тако истичу структурни, каузални и функционални односи између појмова, појава и чињеница које ученици упознају (Николић 2009: 109). 
Ученици су тако подстакнути да уз помоћ средњошколског уџбеника и инструкција наставника решавају задатаке у оквиру припремљеног материјала, врше анализу грађе, синтезу, апстракцију, генерализацију и категоризацију синтаксичких појмова, процеса и законитости и самостално долазе до нових чињеница и података. ${ }^{3}$ Поред лекције Реченице са логичким субјектом они у оквиру неких других текстова из уџбеника, као што су, на пример, лекције о предикату, валенци глагола, различитим типовима реченица и сл. такође могу пронаћи информације које су им неопходне да би урадили задатке, чиме се наводе на самосталност, што је и најважнији васпитни задатак. Таквим приступом постиже се, дакле, индивидуализација у настави српског језика јер сваки појединац, у складу са својим предзнањем и способностима, може одређивати темпо и начин на који ће решавати задатке, односно да ли ће се у већој или мањој мери служити уџбеником или неким додатним материјалом, као што су приручници, ученичке белешке и сл. Иако се улога наставника у таквом методичком приступу претежно своди на давање инструкција за рад са наставним материјалом, он им је у сваком тренутку на располагању уколико су им потребне додатне информације или помоћ, а потврду тачности решења могу добити одмах, што их у раду додатно мотивише. Предност оваквог приступа у обради грађе из синтаксе огледа се, дакле, у сарадничком односу између ученика и наставника који прати ефекте својих поступака у настави, као и промене у самим ученицима, односно у њиховој перцепцији, критичком односу према сазнатом, те мотивацији за даљи и дубљи рад.

При конструисању наставног материјала важно је, такође, да се ученицима са нарочитом мотивацијом, који са посебним интересовањем и лакоћом савладавају градиво предвиђено у оквиру редовне наставе, омогући продубљивање и проширивање знања о моделима реченица са различитим типовима субјекта које ће превазићи садржаје одређене наставним планом и програмом. Наставник им кроз посебне секвенце задатака може представити конструкције са именичким изразима у инструменталу и локативу, које се у савременој лингвистици такође тумаче као семантички, односно логички субјекат. ${ }^{4}$ Такву могућност презентовали смо у оквиру радног материјала кроз посебну, шесту

3 Такав материјал погодан је за часове обраде новог градива о различитим типовима субјекта и реченицама у чијем моделовању учествују, где се у инструкционо-мотивационој фази рада на часу могу актуализовати њихова знања о структурирању субјекатско-предикатске реченице. Згодан је и за обнављање, утврђивање и заокруживање већ стеченог знања о тим синтаксичким појавама, процесима и законитостима, које су ученици раније усвојили применом других наставних метода.

4 Љиљана Петровачки указује на потребу да се нова лингвистичка истраживања у методичким радовима филтрирају за потребе наставе како би се учење матерњег језика у средњој школи осавременило и учинило занимљивијим (2008: 80). 
групу задатака. На тај начин постиже се диференцијација наставе, односно развијају когнитивне и интелектуалне способности надарених појединаца, чиме се, заправо, остварују примарни циљеви школског учења уопште. Квалитет наставе граматике матерњег језика тиме се побољшава и она се усклађује са савременим европским и светским токовима у методичкој науци.

Важно је истаћи и посебан значај контекста у коме примере реченица са различитим типовима субјекта ваља презентовати. Наставник увек треба да има у виду да је изучавање градива из синтаксе сврсисходно у функцији правилног усменог и писменог изражавања ученика, па га стога мора представљати у контексту комуникативних активности. Пошто се поменути модели реченица користе у свакодневној вербалној и писменој комуникацији, такве конструкције могу бити приказане у различитим говорним ситуацијама њима блиским. У ту сврху наставник може представити дијалог остварен усменим путем, али и онај остварен кроз телефонски разговор, имејлове или поруке које се размењују на некој од друштвених мрежа. Пожељно је да такви дијалози буду приказани очигледно, реално или путем слика преписке, што се у пракси може презентовати различито.

С обзиром на то да комерцијална интернетска друштвена мрежа Фејсбук, путем које ученици врло често комуницирају, садржи апликацију чет, односно „ћаскање”, и корисницима пружа могућност да размењују информације у реалном времену, нарочито је згодна за презентовање различитих комуникативних ситуација. Зато смо конструисали лингвометодички предложак у виду визуелног приказа дискурса оствареног путем тог средства комуникације. Сматрамо да ће на тај начин знање из граматике које ученици стичу бити непосредно повезано са њиховом језичком праксом, а правила употребе синтаксичких средстава, попут логичког субјекта, презентована у контексту дискурса.

Да би се грађа из синтаксе приближила ученицима и они препознали смисао изучавања одређених синтаксичких појмова и процеса, дијалог који им се представља може бити заснован на наставниковом познавању њихових интересовања, хобија и талената, као што је бављење спортом, учешће у различитим литерарним, драмским и новинарским секцијама, њихово ангажовање у школском хору, фолклору и сл. Свакако да ће им бити занимљивије да граматичке појаве откривају на примерима из свакодневног живота, где се помињу позната имена и поступци, услед чега ће и њихова мотивисаност и интелектуална активност бити на високом нивоу. На тај начин постижу се бројни позитивни ефекти, ${ }^{5}$ па смо се тиме и водили при конструисању

5 О могућностима контекстуализације грађе из језика и књижевности и значају комуникативног приступа у настави говори Д. Вељковић Станковић (2007), при чему посебно 
примера, настојећи да садржај предлошка прилагодимо средњошколцима и њиховим активностима. Ученицима је тако омогућено боље разумевање полазног текста и функционалније сагледавање језичког проблема у њему.

Потребно је, дакле, осмишљавати наставни процес водећи рачуна о бројним аспектима његове организације, како би облици и садржаји активности ученика и наставника, као и бројни други значајни елементи наставе, били унапред испланирани и организовани те међусобно повезани у јединствену целину. У оваквом методичком приступу предвиђено је да, након што добију материјал, ученици самостално одговоре на постављена питања, уз помоћ средњошколског уџбеника (Станојчић, Поповић 1999), у коме могу пронаћи све полазне информације. Премда је материјал организован тако да се у раду могу ослонити на дефиниције и теоријска одређења нових синтаксичких појмова из уџбеника, неопходно је да при том примене и бројна предзнања о различитим синтаксичким процесима и законитостима како би решили све задатке. Уколико се укаже потреба, наставник им у сваком тренутку може помоћи кроз додатне инструкције и разјашњења, док ће им одговори бити предочени тек након што самостално ураде задатке. У раду су решења дата одмах иза задатака из практичник разлога.

\section{ЗАДАЦИ И УПУТСТВА ЗА САМОСТАЛАН РАД СА УЏБЕНИКОМ}

Област: Неки посебни типови предикатских реченица

Упутство: Пронађи у уџбенику област Неки посебни типови предикатских реченица, и у оквиру те шире целине поглавље 2 (стр. 249) Реченице са логичким (семантичким) субјектом. Пажљиво прочитај садржај о моделовању просте реченице са логичким субјектом и његовим реализацијама (тачке 447, 448, 449 и 450). Прочитај потом доле наведени дијалог и, користећи уџбеник, одговори на постављена питања.

истиче брзину усвајања знања и њихову трајност као значајна преимућства методичких модела заснованих на контекстуализацији наставних садржаја. 
Дуња Васић

+ Нова порука * Радње $>$ Q

Conversation started 26. април

(c) Маја Илић

Ћао, Дуња! Зашто ниси дошла на пробу данас?

Дуња Васић

Позлило ми је синоћ.

Маја Илић

Јаo! Како се сада осећаш?

Дуња Васић

Врти ми се у глави. Уморна сам. Стално ми се спава.

Штета... Баш ми се плесало.

(9. Маја Илић

Многима је било лоше ових дана. Сигурно је неки грип. Уф, како ћу без вас?

Досадно ми је. Иначе, наставник се наљутио... Дозлогрдило му је. Много смо изостајали. Севале су му очи!

\section{Дуња Васић}

Трудио се око припрема... Жао ми га је. Међутим, нисмо ми криви! Ану је ухватила прехлада. Звала сам је. њој је боље. А Сању је заболео зуб. Ишла је код зубара... Није јој ни до чега.

(.) Маја Илић

Рекли смо му. Сутра неће бити пробе. Нећемо имати часове до краја недеље. Ваљда ће се група окупити у понедељак.

\section{Дуња Васић}

Сада ме је страх. Хоћемо ли увежбати кореографију на време?!

\section{Маја Илић}

Не бојим се такмичења. Увек будемо одлични!

Дуња Васић

Тако је! Радују ме нови наступи и победе!

Маја Илић

Чујемо се сутра! Крчи ми у стомаку. Одох у кухињу.

Дуња Васић

Важи! Ево, и мени се једе...

Маја Илић

Брзо оздрави! 


\section{I ДЕО}

1. Пажљиво сагледај наведене реченице:

1. Ваљда ће се наша група окупити у понедељак.

2. Иначе, наставник се наљутио.

a) Наведени примери илуструју основни тип просте реченице у српском језику, а то је

б) У њеном саставу налазе се два главна реченична конституента и

Одговори: а) субјекатско-предикатска реченица; б) субјекат и предикат.

2. а) Подвуци предикат у примерима из претходног задатка.

б) Предикатом се у њима означава

в) Тип синтаксичке јединице у издвојеним предикативима је

г) У лексичком језгру оба предиката налази се па такав типичан облик предиката називамо

д) Попуни табелу тако што ћеш извршити морфолошку анализу речи у служби предиката: ${ }^{6}$

\begin{tabular}{|l|l|l|}
\hline ПРЕДИКАТ & ће се окупити & се наљутио \\
\hline ВРСТА РЕЧИ & глагол & глагол \\
\hline ЛИЦЕ & 3. лице & 3. лице \\
\hline РОД & женски род & мушки род \\
\hline БРОЈ & једнина & једнина \\
\hline
\end{tabular}

ђ) Обрати пажњу на предикат у реченици из дијалога: Увек будемо одлични. У његовом лексичком језгру налази се а такав предикат називамо и њиме се субјекат

Одговори: а) ће се окупити, се наљутио; б) радња и стање; в) реч; г) глагол; д) глаголски предикат; Ђ) придев; именски предикат; квалификује.

6 Премда ће одговори ученицима бити предочени тек након што самостално ураде задатке, ради прегледности, презентоваћемо их у табелама. 
3. а) Заокружи субјекат у примеру бр 1. из првог задатка.

б) У служби субјекта у тој реченици као тип синтаксичке јединице налази се:

в) Заокружи субјекат у примеру бр. 2 из првог задатка.

г) У служби субјекта у тој реченици као тип синтаксичке јединице налази се:

д) Изврши морфолошку анализу субјеката у прва два примера:

\begin{tabular}{|l|l|l|}
\hline СУБЈЕКАТ & нама група & наставник \\
\hline ВРСТА РЕЧИ & присвојна заменица + именица & именицуа \\
\hline ПАДЕЖ & номинатив & номинатив \\
\hline РОД & женски род & муики род \\
\hline БРОЈ & множина & једнина \\
\hline
\end{tabular}

ђ) Именички израз у таквом падежном облику може се означити и као субјекат.

Одговори: а) наша група; б) синтагма; в) наставник; г) реч; Ђ) ГРАМАТИЧКИ СУБЈЕКАТ.

4. а) Ко врши функцију субјекта у примеру: Увек будемо одлични. (обрати пажњу на дијалог!)?

б) Уколико субјекат у реченици није експлицитно исказан, на основу чега закључујемо ко ту функцију врши?

г) Конструиши реченицу са придевом одличан у функцији предикатива, где ће субјекат бити исказан зависном, односном реченицом.

Одговори: а) плесна група/ разред; б) на то упућуjу наставци личног глаголског облика у предикату/ на основу контекста, комуникативне ситуације; г) могући одговор: Ко се добро припреми, буде одличан на наступу.

5. Одреди на који начин је основни субјекатско-предикатски модел реченице допуњен у примеру: Ваљда ће се наша група окупити у понедељак.

Одговор: допуном за време - у понедељак. 
6. Обрати пажњу на морфолошке аспекте речи и синтагми у служби субјекта и предиката. У каквом су они односу у наведеним примерима?

Одговор: Субјекат и предикат конгруирају, слажу се у роду, броју и nадежу.

\section{ІІ ДЕО}

1. Пажљиво сагледај следеће примере:

1. Позлило ми је синоћ.

2. Баш ми се плесало.

3. Врти ми се у глави.

4. Стално ми се спава.

a) Подвуци предикате у наведеним реченицама.

б) Одреди која је њихова функција - шта означавају.

Одговори: а) позлило је, се плесало, се врти, се спава; б) означавају одређени ситуаиију, односно психофизичко стање, жељу, вољу.

2. а) Обрати пажњу на дијалог. Ко је носилац ситуација исказаних у сваком од четири примера из претходног задатка?

б) Да ли је у издвојеним реченицама носилац ситуације експлицитно означен граматичким субјектом?

в) На основу ког сегмента у реченицама закључујемо ко је носилац ситуације, односно субјекат?

г) У ком зависном падежу стоји именичка јединица којом се означава носилац ситуације?

Одговори: а) Дуња; б) носилаи ситуачије није експлицитно исказан; в) на основу заменице ,ми”; г) у дативу.

3. Именичка јединица употребљена у као падежном облику која врши службу носиоца ситуације назива се или СУБЈЕКАТ.

Разликујемо га од именичког израза у као падежном облику, који прецизније означавамо као или СУБЈЕКАТ.

Одговори: дативу, ЛОГИЧКИ, СЕМАНТИЧКИ, номинативу, ПРАВИ, ГРАМАТИЧКИ. 
4. Транформиши следеће примере у реченице са глаголом у облику перфекта и граматичким субјектом.

\begin{tabular}{|l|l|}
\hline Позлило ми је синоћ. & Ја сам се синоћ разболела. \\
\hline Баш ми се плесало. & Ја сам синоћ пожелела плесати. \\
\hline Врти ми се у глави. & Ја сам имала вртоглавищу. \\
\hline Стално ми се спава. & Ја сам била поспана. \\
\hline
\end{tabular}

* У табели су наведени могући одговори.

5. Пажљиво прочитај дијалог још једном, а потом изврши семантичку анализу издвојених примера - одреди носиоче расположења, физиолошке потребе, физиолошког стаға/прочеса, осећања, воље/ жеље и сл. према моделу:

\begin{tabular}{|c|c|c|}
\hline Ево, и мени се једе. & MAJA & носилац физиолошке потребе \\
\hline Није јој ни до чега. & Сања & носилац воље/жеље \\
\hline Дозлогрдило му је. & наставник & носилач раположења \\
\hline Крчи ми у стомаку. & Дуња & носилаи физиолоиког стања/проиеса \\
\hline Жао ми га је. & Дуњьа & носилаи осећања \\
\hline
\end{tabular}

6. а) Одреди тип предиката у следећим реченицама:

Севале су му очи.

Њој је боље.

Синоћ ми је позлило.

Спава ми се.

Многима је било лоше ових дана. том?

б) Ком типу реченице припадају наведени примери са логичким субјек-

в) Да ли логички (семантички) субјекат у дативу и предикати у наведеним примерима конгруирају?

Одговори: а) глаголски предикат, прилошки предикат, глаголски предикат, глаголски предикат, прилочки предикат; б) Севале су му очи. - лична (субјекатско-предикатска реченица), Њој је боље. - безлична реченица, 
Синоћ ми је позлило - безлична реченица, Спава ми се. - безлична реченица, Многима је било лоше ових дана. - безлична реченица; в) не конгруира са глаголом у служби предиката.

7. Изврши морфосинтаксичку анализу реченице: Досадно ми је. Попуни табелу:

\begin{tabular}{|c|c|c|c|}
\hline $\begin{array}{c}\text { Конституентска } \\
\text { јединица }\end{array}$ & $\begin{array}{c}\text { Тип јединице и } \\
\text { њено лексичко } \\
\text { језгро }\end{array}$ & $\begin{array}{c}\text { Конституентски } \\
\text { облик }\end{array}$ & $\begin{array}{c}\text { Синтаксичка } \\
\text { функција и } \\
\text { дистрибуција }\end{array}$ \\
\hline досадно & $\begin{array}{l}\text { прилог } \\
\text {,досадно” }\end{array}$ & - & $\begin{array}{l}\text { - прилошки део } \\
\text { предиката у } \\
\text { безличној реченищи }\end{array}$ \\
\hline ми & заменица „jа” & датив & $\begin{array}{l}\text { - логички } \\
\text { (семантички) } \\
\text { субјекат у } \\
\text { безличној реченищи }\end{array}$ \\
\hline je & глагол „јесам” & 3. л. јд. презента & $\begin{array}{l}\text { - глаголски део } \\
\text { предиката у } \\
\text { безличној реченищи }\end{array}$ \\
\hline
\end{tabular}

8. Састави пет реченица у којима ћеш употребити логички субјекат у дативу.

Могући одговори: Жури ми се. Хладно ми је. Данас ми се не кува. Не ради ми се. Није ми до трчања.

\section{ІІІ ДЕО}

1. Пажљиво прочитај следеће примере:

1. Ану је ухватила прехлада.

2. Радују ме нови наступи и победе!

a) Подвуци предикате у наведеним реченицама.

б) Именице прехлада, наступи и победе у реченицама су исказане у као падежном облику, те стога врше службу 
в) Међутим, обрати пажњу на дијалог! Носилац ситуације, односно физиолошког стања у првој реченици је , док је носилац психолошког стања у другом примеру

г) У ком падежу су исказани носиоци ситуација у наведеним примерима?

д) Именица Ана у првом примеру и енклитички облик заменице $j a$ у другом примеру, стога, врше функцију

ђ) Транформиши наведене примере у реченице са правим, граматичким субјектом који ће бити носилац ситуације и именским предикатом.

Одговори: а) је ухватила, радују; б) номинативу, граматичког субјекта; в) Ана, Дуюа; г) акузативу; д) логичког (семантичког) субјекта; Ђ) могући одговори: Ана је прехлађена, Ја сам радосна због нових наступа и победа!

2. Пажљиво прочитај следећу реченицу:

А Сању је заболео зуб.

a) Подвуци предикат у том примеру.

б) Какав тип ситуације је исказан предикатом у издвојеној реченици?

в) Ко је носилац ситуације у датом примеру - Сања или зуб?

г) Носилац ситуације у реченици исказан је у као падежном облику, а такав тип субјекта

назива се

д) Састави две реченице са правим, граматичким субјектом (који ће истовремено бити и носилац ситуације!) - једну у којој ће именица Caњa вршити ту функцију и једну у којој ће именица зуб бити субјекат.

Одговори: а) је заболео; б) физиолошко стање/проиес; в) Соња; г) акузативу, логички (семантички) субјекат; д) могући одговори: Сања има покварен зуб. Зуб је беле боје. 
3. а) Пронађи у тексту још један пример реченице у којој је употребљен логички (семантички) субјекат у акузативу.

б) Трансформиши наведени пример у реченицу са правим (граматичким) субјектом коју је Дуња, такође, могла употребити у дијалогу.

Одговори: а) Сада ме је страх; б) могући одговор: Ја се сада плашим.

4. Осмисли четири реченице са логичким (семантичким) субјектом у акузативу - две којима ће бити исказано психолошко и две којима ће бити исказано физиолошко стање или процес.

Могући одговори: Нервира ме лењост. Брине ме школски успех. Боли ме глава. Дуьу је занела вртоглавииа.

\section{IV ДЕО}

1. Одреди ком типу реченице припада следећи пример:

Сутра неће бити пробе.

Одговор: безлична егзистениијална реченица.

2. Подвуци предикат у реченици из претходног задатка.

Одговор: неће бити.

3.Одредилогичкисубјекатуистојреченици.

Одговор: пробе.

4. Шта именује логички субјекат у наведеном примеру?

Одговор: логички субјекат именује појам о чијој је егзистенцији реч.

5. У ком падежном облику се налазилогички субјекат?

Одговор: стоји у облику генитива. 
6. Којим реченичним чланом је проширен основни субјекатско-предикатски модел реченице у наведеном примеру, односно коју функцију тај члан врши у реченици?

Одговор: проширен је одредбом за време-сутра.

7. Осмисли безличну егзистенцијалну реченицу са сличним значењем, али тако што ћеш употребити други глагол (у презенту).

Могући одговор: Сутра нема пробе.

8. Осмисли три своја примера безличних егзистенцијалних реченица са логичким (семантичким) субјектом у генитиву.

Могући одговори: Ове зиме није било снега. Биће врућине на лето. Има добрих људи.

\section{V ДЕО}

1. Субјекат је независни реченични конституент којим се означава

Одговор: носилац ситуације именоване и приписане предикатом.

2. Према типу конституентске јединице субјекат је

Одговор: именичка јединица, тј. именица, именичка синтагма или лична или нелична заменица (с тим ито се лична заменица може и само подразумевати).

3. Конституентски облик субјекта најчешће је и такав тип субјекта називамо

или _ субјекат.

Одговори: именичка јединица у номинативу, тј независном падежу; прави, граматички субјекат.

4. Именичка јединица у зависном падежу или ) такође може именовати појам о 
коме се говори у реченици, а такав субјекат називамо или

субјекат.

Одговори: дативу, акузативу или генитиву, логички, семантички субјекат.

\section{VI ДЕО $\boldsymbol{O}^{7}$}

Прочитај наставак дијалога:

\section{Маја Илић}

\section{+ New Message * Actions $\nabla \mathrm{Q}$}

\section{Маја Илић}

Како се осећаш данас?

\section{Дуња Васић}

Хеј, пошло је набоље с мојим здрављем! Мало сам побледела у лицу. Међутим, лекар је задовољан. Грип се јавио у блажем облику.

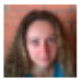

\section{Маја Илић}

Једва чекам понедељак. Опет ћу бити окружена пријатељима.

\section{Дуња Васић}

Окупићемо се сви. Радује ме такмичење, али га се и прибојавам. Ради се, ипак, о нашој будућности.

\section{Маја Илић}

Тре6а да се опустимо. Не смемо 6ити оптерећени проблемима. Охрабрени претходним успесима вредно ћемо вежбати. (-)

\section{Дуња Васић}

Тако је! На такмичењу ће жири бити освојен нашом игром и песмом. Ношени бодрењем навијача из школе сигурно ћемо победити!

7 Због комплекснијих реченичних конструкција ова секвенца намењена је за диференцијацију наставе, тј. за надарене ученике, који су заинтересовани за дубље изучавање грађе из синтаксе просте реченице, а тиме и за темељнију обраду градива о реченицама са логичким (семантичким) субјектом у српском језику. 
1. Пажљиво прочитај реченицу:

Хеј, пошло је набоље с мојим здрављем!

а) Одреди ко је носилац ситуације у наведеној реченици и подвуци га.

б) Којим падежним обликом је исказан носилац дате ситуације?

в) Како називамо именичку јединицу у зависном падежу којом се именује појам о коме се говори у реченици?

г) Транформиши реченицу тако да носилац ситуације буде истовремено и прави, граматички субјекат.

Одговори: а) моје (Дунино) здравље; б) инструменталом, в) логички (семантички) субјекат; г) могући одговор: Моје здравље се побољиало.

2. Пажљиво прочитај реченице:

1. Oпет ћу бити окружена пријатељима.

2. На такмичењу ће жири бити освојен нашом игром и песмом.

a) Облик глагола у служби предиката који налазимо у два издвојена примера назива се

б) Наведени примери припадају посебном типу предикатске реченице који се назива или

в) У првом примеру агенс је , а пацијенс ,апацијенс , док је у другом примеру агенс (обрати пажну на дијалог!).

г) Вршилац радње у наведеним примерима исказан је, дакле, у зависном падежу, односно , и он у реченицама врши синтаксичку функцију

д) Трансформиши наведене реченице у примере са активном конструкцијом тако што ћеш употребити прави, граматички субјекат у номинативу.

Одговори: а) партиципски пасив; б) пасивна реченицуа - реченица са пасивном конструкиијом; в) пријатељь, ја (Дуюа), наша игра и песма, жири; г) инструменталу, логичког (семантичког) субјекта; д) могући одговори: 
Пријатељи ће ме опет окружити. Наша игра и песма освојиће жири на такмичењу.

3. Пронађи у дијалогу још неколико примера са логичким (семантичким) субјектом у инструменталу и транформиши их у реченице са граматичким (правим) субјектом у номинативу. Попуни табелу:

\begin{tabular}{|c|c|c|}
\hline $\begin{array}{l}\text { ВЕЖБА } \\
\text { ТРАНСФОРМАЦИЈЕ }\end{array}$ & $\begin{array}{l}\text { Реченице са логичким } \\
\text { (семантичким) } \\
\text { субјектом }\end{array}$ & $\begin{array}{l}\text { Реченице са } \\
\text { граматичким } \\
\text { субјектом }\end{array}$ \\
\hline $\begin{array}{l}\text { Трансформација } \\
\text { примера са логичким } \\
\text { субјектом у } \\
\text { инструменталу }\end{array}$ & $\begin{array}{l}\text { - Не смемо бити } \\
\text { оптерећени } \\
\text { проблемима. - } \\
\text { Охрабрени претходним } \\
\text { успесима вредно ћемо } \\
\text { вежбати. } \\
\text { - Ночени бодренем } \\
\text { навијача из иколе } \\
\text { сигурно ћемо победити! }\end{array}$ & $\begin{array}{l}\text { - Проблеми нас не смеју } \\
\text { оптерећивати. } \\
\text { - Претходни успеси ће } \\
\text { нас охрабрити, па ћемо } \\
\text { вредно вежбати. } \\
\text { - Бодрење навијача из } \\
\text { школе ће нас носити, } \\
\text { па ћемо сигурно } \\
\text { победити! }\end{array}$ \\
\hline
\end{tabular}

*У другој колони наведени су могући одговори.

4. Пажљиво прочитај следеће реченице:

1. Мало сам побледела у лииу.

2. Грип се јавио у блажем облику.

a) Подвуци предикат у наведеним примерима.

б) У првом примеру прави, граматички субјекат је , што сазнајемо на основу

в) У датом примеру предлошко - падежна конструкција у лииу врши функцију

Стога је могуће транформисати реченицу тако да реч лище врши функцију правог, граматичког субјекта, на пример:

г) Подвуци логички (семантички) субјекат у другом примеру.

д) Његов падежни облик је

ђ) Тип синтаксичке јединице у служби семантичког субјект у том примеру je 
е) Трансформиши други пример тако да синтаксичка јединица која у њему врши функцију семантичког субјекта у конструисаној реченици врши функцију правог, граматичког субјекта.

Одговори: а) сам побледела, се јавио; б) ја (Дуња), наставка за лични глаголски облик и контекста, комуникативне ситуаџије; в) логичког (семантичког) субјекта, могући одговори: Лице ми је побледело.; г) у блажем облику; д) локатив; Ђ) синтагма; е) могући одговор: Код мене се појавио блажи облик грипа.

5. Пронађи у дијалогу још један пример са логичким (семантичким) субјектом у локативуу и транформиши га у реченицу са граматичким (правим) субјектом у номинативу. Попуни табелу:

\begin{tabular}{|l|l|l|}
\hline $\begin{array}{l}\text { ВЕЖБА } \\
\text { ТРАНСФОРМАЦИЈЕ }\end{array}$ & $\begin{array}{l}\text { Реченица са логичким } \\
\text { (семантичким) } \\
\text { субјектом }\end{array}$ & $\begin{array}{l}\text { Реченица са } \\
\text { граматичким } \\
\text { субјектом }\end{array}$ \\
\hline $\begin{array}{l}\text { Трансформација } \\
\text { примера са логичким } \\
\text { субјектом у локативу }\end{array}$ & $\begin{array}{l}\text { Ради се, ипак, о намој } \\
\text { будућости. }\end{array}$ & $\begin{array}{l}\text { Наша будућност је y } \\
\text { питағу. }\end{array}$ \\
\hline
\end{tabular}

6. Допуни дефиницију: Логички (семантички) субјекат у српском језикy jecme

, а може бити исказан

у различитим падежним облицимма односно:

Одговор: именичка јединица којом се именује појам о коме се говори у реченици; зависним падежима - дативу, акузативу и генитиву, али и инструменталу и локативу у неким посебним типовима реченица.

\section{3. ЗАКЉУЧНЕ НАПОМЕНЕ}

Савремена концепција стицања нових знања из граматике подразумева то да ученици имају улогу активних и самосталних учесника у настави, при чему знање стичу постепено, корак по корак, сопственим темпом, уз 
могућност сталне и правовремене контроле, али и помоћ наставника који има задатак да их у васпитно-образовном процесу води и мотивише за даљи рад. Методички приступ који смо презентовали омогућава остварење поменутих циљева и треба га уводити у наставу онда када нам природа градива то дозвољава. Синтаксичка грађа о моделима просте реченице са граматичким и логичким субјектом погодна је за логичко рашчлањивање и сегментирање, те за моделовање полупрограмираног материјала и његово коришћење у настави. Премда израда секвенци задатака од наставника тражи времена и напора, потребно их је уводити у школску праксу јер се на тај начин подстиче активан однос ученика према наставним садржајима из језика, при чему се оспособљавају за самостално учење.

\section{ЛИТЕРАТУРА}

Вељковић Станковић, Д. (2010). Комуникативни приступ у настави српског језика. Узданица, 7(1), 7-17.

Илић, П. (2003). Српски језик и књижевност у наставној теорији и пракси. Методика наставе. Нови Сад: Змај.

Николић, М. (2009). Методика наставе српског језика и књижевности. Београд: Завод за уџбенике и наставна средства.

Петровачки, Љ. (2008). Методичка истраживања у настави српског језика и књижевности. Нови Сад: Филозофски факултет.

Петровачки, Љ., \& Штасни, Г. (2010). Методички системи у настави српског језика и књижевности. Нови Сад: Филозофски факултет.

Пипер, П., Антонић, И., Ружић, В., Танасић, С., Поповић, Љ. \& Тошовић, Б. (2005). Синтакса савременог српског језика (Проста реченица). Нови Сад: Матица српска.

Правилник о Наставном плану и програму за обдарене ученике у филолошкој гимназији.(1997). Просветни гласник. 110-00-32/97-01.

Станојчић, Ж., \& Поповић, Љ. (1999). Граматика српског језика. Београд: Завод за уџбенике и наставна средства. 


\section{Milica M. Savić}

\section{MODELS OF SIMPLE CLAUSE BASED ON SUBJECT TYPES IN SERBIAN LANGUAGE CURRICULUM}

\section{Summary}

Based on the relevant literature in linguistics and teaching methodology, the paper analyzes possibilities for planning a Serbian language curriculum unit on subject, as one of the basic constituents in a clause, and on its typology. The methodological model is described based on contemporary methodological systems, and the directions are given for the effective study of complex models of a simple clause with grammatical and semantic (logical) subject for high schools using a study book and a semi-programmed material.

Key words: Serbian language curriculum methodology, syntax, simple clause, logical subject, semi-programmed curriculum material. 